\title{
Fintech developmental trends: the role and influence of sustainable digital logistics
}

\author{
Anna Svirina ${ }^{1,}{ }^{*}$, Natalia Appalonova ${ }^{2}$, Dmitry Garanin ${ }^{3}$, Nikita Lukashevich $^{3}$, and Igor \\ Koshkin ${ }^{4}$ \\ ${ }^{1}$ Kazan National Research Technical University named after A.N.Tupolev - KAI, 10, K. Marksa str., \\ 420111, Kazan, Russia \\ ${ }^{2}$ TISBI University of Management, Mushtari street. 13, 420012, Kazan, Russia \\ ${ }^{3}$ Peter the Great St. Petersburg Polytechnic University, 29, Polytechnicheskaya str., 195251, St. \\ Petersburg, Russia \\ ${ }^{4}$ NLC "A.Baitursynov Kostanay Regional University", Kostanay, Republic of Kazakhstan
}

\begin{abstract}
The paper analyzes the current trends of fintech companies' development in relation to the quality of digital logistics. By using the data from fintech companies' CEO interviews, we assess the key trends in fintech companies' development over the past 3 years, reveal key technologies used by these companies and their evolution, and state the importance and relevance of digital logistics issues for fintech companies clients' satisfaction. The research indicates that for fintech company client the ease of getting through the service (optimization of information flows) appears to be more important than other characteristics of the offered product. From the theoretical point of view, our research indicates, that besides key growth driving factors, outlined in existing literature, such as strategy, prerequisites for rapid growth, business model choice, international business networks, entrepreneur's characteristics, product development or theoretical frameworks for development, especially within the international market, the quality of digital logistics performance of fintech companies seem to matter.
\end{abstract}

\section{Introduction}

The latter development of financial industry is gradually attracting more attention to the issues that were considered unimportant several years ago. In the first place it is related to rapid digitalization of the financial sector that leads to several problems and outcomes including the issues of data storage, cyber security, data transmission and a few others. Among those one can name the problems of handing information flows that refer to the field of digital logistics; especially, with the development of internet-banking and internetinvestments, accompanied by switching to algorithms in client relations, the issues of efficient management of information flows becomes a highly important one - not only from the technical, but also from the managerial point of view.

In this paper we will be assessing the evolution of digital financial sector in relation to the digital logistics factor, in pursuit to estimate what role and influence does digital logistics

\footnotetext{
* Corresponding author: aasvirina@kai.ru
} 
issues have on fintech sector company performance. To achieve this goal, we at first estimate the most promising sectors in digital companies' development and then go in-depth to fintech information flows based on evidence from the interviews with the companies applying to fintech startup accelerating programs. Thus, the research question of this paper is to define the level to which extend digital logistics characteristics influence the trends of financial technology companies' development now.

\section{Materials and Methods}

\subsection{An overview on digital companies development}

Basic analysis of digital companies development indicates one can find several approaches towards theoretical and practical basement of startups development in the information sector. Some authors assume that startup development has to be evaluated alongside theoretical frameworks, such as resource-based theory $[1,2]$, the concept of resources and competences [3] or institutional theory [4]. Other direction of existing research states that one can find special instruments for pursuing efficient internationalization tactic $[5,6]$ and in future these practices can be replicated. This line is also followed by the researchers who indicate the importance of CEO attributes [7], human capital [8, 9]; size [10]; innovation [11] or networks [12].

Another significant line of research is dealing with the factor models on SME development $[13,14]$ to develop the integral model of efficient entrance of international markets. Within this line some of the researchers have focused on strategy [15], prerequisites for rapid growth [16], business model choice [17] or international business networks [18], each of those have appeared to be a significant factor for international development of the early stage companies. Making these findings integral, the authors argued for effectuation approaches [19], entrepreneur's characteristics [20], product development [21] or theoretical frameworks for development, especially within the international market [22]. Yet, all of these were mainly focusing on companies' self-assessment in a form of questionnaires and on performance data, rather than on external evaluation, and also do not pay much attention towards digital world factors that appear to be different from the traditional ones.

\subsection{An outline of fintech and banking research}

Since this research is aiming to understand the role of digital logistics not for all digital companies, but focuses on fintech, it seems relevant to have a brief overview of the state of art in fintech and banking sector development research.

According to [23], fintech is an element of current rapid digitalization and financial innovation; it is theoretically based on the specific value provided to the customers in the financial sector by giving clients higher flexibility without involving additional risks [24] and still supporting existing traditional value ensured by the financial companies [25] The Financial Stability Board defines fintech as "technologically enabled financial innovation that could result in new business models, applications, processes, products with an associated material effect on financial markets". In this paper we follow the latter definition and see fintech as a spin-off of financial industry that aims to use digital innovation for traditional financial purposes.

Following this statement, we have to agree with [26] that "Digital innovations and technology based business models could provide new business opportunities for incumbents, by transforming how they create value and deliver products and services. Or they could disrupt the existing structure of the financial industry, by blurring its boundaries and fostering 
strategic disintermediation. By providing new gateways for entrepreneurship, Fintech can ease the access to financial services, fostering competition by new players. To survive, incumbent banks will have to react, face rising competitive pressure and adopt new strategies". Thus, fintech becomes a factor that significantly influences what is happening in the industry at the point, and leads us to the research question stated above - if we agree that fintech has the influence on financial sector development, to what extend does the digital logistics factor influence fintech companies' development trends?

\section{Results}

\subsection{Methodology overview}

For the purposes of this study we have used the evaluation forms from a venture capital fund, filled by the experts that contact the companies on pre-assessment stage that is performed by investment analytics. The experts hold a 30-minutes long interview with the startup owners (digital startups only were involved) which has a brief script, and fill out the evaluation form afterwards; some information filled by the owners of digital companies is available to the experts prior to an interview. The interviewers were the people from industry with IT-relevant experience.

The interviews are being run in a form of unstructured interviews, when the interviewer has no specific guidelines, restrictions, predetermined questions, or list of options. The interviewer asks a few broad questions to engage the respondent in an open, informal, and spontaneous discussion. The interviewer also probes with further questions and/or explores inconsistencies to gather more in-depth information on the topic. Unstructured interviews are particularly useful for getting the stories behind respondents' experiences or when there is little information about a topic, and this is the reason why venture funds prefer this form of interaction with SMEs rather than giving a script to an interviewer - in about half of the cases significant information would have skipped the investment analytics if it was not for the interview. The interviews are being held in line with the instructions given, for instance, in [27-31].

The analyzed sample included over 200 startups related to fintech, which were interviewed between 2017 and 2020; the results of the interviews were provided by the experts who disguised the companies which were being interviewed.

\subsection{Key research outcomes}

On the first stage of the analysis we have assessed the main technologies which were implemented by the digital startups (here and further were used for visualizations of the structures), which can be seen on Fig. 1. Though all the search digital companies were to some extend related to the fintech industry, at this point we have defined which ones can be considered clearly "financial technologies" ones, and the others when their key technology can be used in other sectors as well as financial.

As one can derive from Fig.1, key technologies implemented by fintech companies in three year period were blockchain, dig data, machine learning and artificial intelligence. 


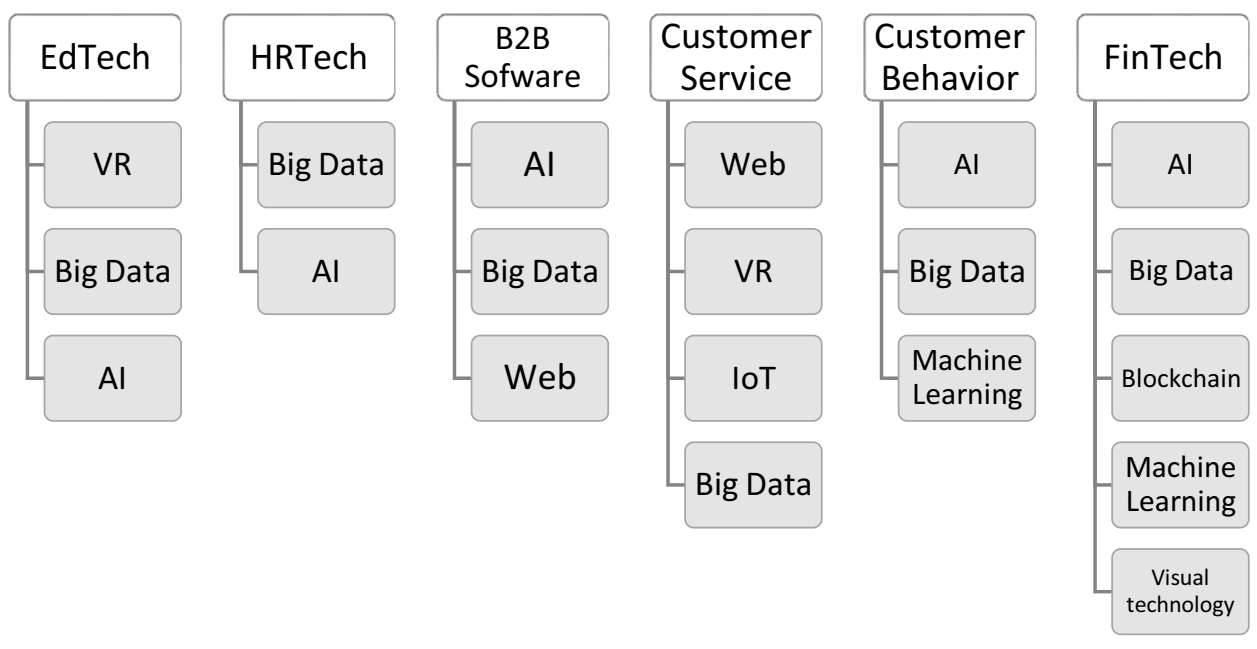

Fig. 1. The main implementation areas and used digital technologies (sample-based).

However, the latest findings confirm the shift in these technologies - blockchain was driven out by big data analysis (including visual data) and semantic systems based on recognition of voices. Both are connected to machine learning and artificial intelligence systems that filter clients and shape their paths based on revealed data. The distribution of these technologies in fintech startups is shown on Fig. 2.

\begin{tabular}{|c|c|}
\hline AI & \multirow{2}{*}{ Machine Learning } \\
\hline Big Data & \\
Blockchain & Visual Technologies \\
\hline
\end{tabular}

Fig. 2. The main implementation areas and used digital technologies (sample-based, 2020).

Besides the conclusions indicated above, the Figure reveals the raise of visual technologies in fintech industry. The changed structure of key technologies allows us to define that digital logistics issues are becoming more important; this has to do with the necessity of acquiring, storing and transforming clients data (coming in different formats) and optimizing user experience in fintech companies. To define how significant is digital logistics' influence on that, we have carried out correlation analysis of clients' satisfaction in relation to technologies used in fintech part of our sample. The results can be seen in Table 1. 
Table 1. Pearson correlation of the customer experience and satisfaction and digital characteristics of the product.

\begin{tabular}{|c|c|c|c|c|c|c|c|}
\hline & & PN & PR & TI & DLG & $\mathbf{U X}$ & $\mathrm{CS}$ \\
\hline \multirow{3}{*}{$\begin{array}{l}\text { Product } \\
\text { nativity } \\
\text { (PN) }\end{array}$} & Correlation & 1 & $307^{*}$ & $.797^{* *}$ & $.719^{* *}$ & $.649^{* *}$ & $.625^{* *}$ \\
\hline & Significance & & .000 & .000 & .000 & .000 & .000 \\
\hline & $\mathrm{N}$ & 125 & 119 & 115 & 106 & 107 & 102 \\
\hline \multirow{3}{*}{$\begin{array}{l}\text { Product } \\
\text { relevance } \\
(\mathrm{PR})\end{array}$} & $\begin{array}{l}\text { Pearson } \\
\text { correlation }\end{array}$ & $.307^{*}$ & 1 & $.739^{* *}$ & $.706^{* *}$ & $.798^{* *}$ & $.530^{* *}$ \\
\hline & Sign. (2-tailed) & .000 & & .000 & .000 & .000 & .000 \\
\hline & $\mathrm{N}$ & 119 & 122 & 115 & 104 & 104 & 100 \\
\hline \multirow{3}{*}{$\begin{array}{l}\text { Technolog } \\
\text { y intensity } \\
\text { (TI) }\end{array}$} & $\begin{array}{l}\text { Pearson } \\
\text { correlation }\end{array}$ & $.797^{* *}$ & $.739^{* *}$ & 1 & $.692^{* *}$ & $.552^{* *}$ & $.408^{*}$ \\
\hline & Sign. (2-tailed) & .000 & .000 & & .000 & .000 & .000 \\
\hline & $\mathrm{N}$ & 115 & 115 & 119 & 104 & 105 & 102 \\
\hline \multirow{3}{*}{$\begin{array}{l}\text { Digital } \\
\text { logistics } \\
\text { optimizati } \\
\text { on (DLG) }\end{array}$} & $\begin{array}{l}\text { Pearson } \\
\text { correlation }\end{array}$ & $.719^{* *}$ & $.706^{* *}$ & $.692^{* *}$ & 1 & $.835^{* *}$ & $.755^{* *}$ \\
\hline & Sign. (2-tailed) & .000 & .000 & .000 & & .000 & .000 \\
\hline & $\mathrm{N}$ & 106 & 104 & 104 & 106 & 102 & 99 \\
\hline \multirow{3}{*}{$\begin{array}{l}\text { User } \\
\text { experience } \\
\text { (UX) }\end{array}$} & $\begin{array}{l}\text { Pearson } \\
\text { correlation }\end{array}$ & $.649^{* *}$ & $.798^{* *}$ & $.552^{* *}$ & $.835^{* *}$ & 1 & $.800^{* *}$ \\
\hline & Sign. (2-tailed) & .000 & .000 & .000 & .000 & & .000 \\
\hline & $\mathrm{N}$ & 107 & 104 & 105 & 102 & 107 & 100 \\
\hline \multirow{3}{*}{$\begin{array}{l}\text { Customer } \\
\text { satisfactio } \\
\text { n (CS) }\end{array}$} & $\begin{array}{l}\text { Pearson } \\
\text { correlation }\end{array}$ & $.625^{* *}$ & $.530^{* *}$ & $.408^{*}$ & $.755^{* *}$ & $.800^{* *}$ & 1 \\
\hline & Sign. (2-tailed) & .000 & .000 & .000 & .000 & .000 & \\
\hline & $\mathrm{N}$ & 102 & 100 & 102 & 99 & 100 & 102 \\
\hline
\end{tabular}

As one can derive from the Table above, both customer satisfaction and user experience are strongly related to the digital logistics optimization. In case of customer satisfaction, the correlation is even stronger, than with product relevance, meaning, that even a relevant product can provide great dissatisfaction for the customer if his or her experience with information flows is uncomfortable. The fact of product nativity also influences customer satisfaction less, than logistics optimization.

From the customers' point of view, as described by the fintech companies' founders, the reasoning behind our findings was the following. Even for the relevant products it mattered significantly how quick could the customer get to the provided service itself (i.e., how many steps did he or she had to undertake). On the other hand, it is much less relevant, what type and to what extend does the startup use certain digital technology. From the point of practical takeaways this means that customers tend to evaluate the quality not by technical characteristics, but from the point of convenience and having minimum steps to undertake in order to achieve the result, when dealing with fintech products. Taking into consideration, that financial products are already complicated due to the need to comply with financial authority requirements and cyber security issues, more attention should be given to the optimization of digital logistics as a key factor of customer satisfaction in the end of the day.

\section{Discussion}

The purpose of the study was to measure to which extend digital logistics characteristics influence the trends of financial technology companies' development in the current situation. As our research had indicated, optimization of digital logistics becomes a key factor to acquire customer satisfaction while providing fintech products and services, and also is a 
significantly influential factor when it comes to assessment of user experience. From the customers' point, it is the number of steps he has to undertake to acquire desired result from fintech service, that indicates the quality of service. Thus, our research revealed that customers in the field are driven not by the possibility to use innovative products, but by the usability and convenience, meaning companies are to pay attention to both.

From the theoretical point of view, our research indicates, that besides key growth driving factors, outlined in existing literature, such as strategy [15], prerequisites for rapid growth [16], business model choice [17] or international business networks [18], entrepreneur's characteristics [20], product development [21] or theoretical frameworks for development, especially within the international market [22], the quality of digital logistics performance of fintech companies seem to matter.

\section{Conclusions}

The latter conclusions define the area for future research. It seems relevant to assess whether the significance of digital logistics has the same level of importance not only in financial technology sector, but also in the other digital technology fields. These issues were in a spotlight for practical assessment, yet we still lack academic evaluation in the area. Still, in implementing this research we must consider that the data comes from startup CEO interviews, and it's their perception of user experience and customer satisfaction, that might differ from the data collected by other means.

The practical implications for this study are the most risky areas for the investors into the digital fintech startups. As our research had revealed, customer satisfaction, which is most relevant to startup success, is less significantly related to technology intensity compared to digital optimization of user experience. Hence, the practitioners can have understanding of the role of factors in pursuit for fintech companies' success in the open market. Based on that, future practical oriented research might be in the user experience detailed analysis in fintech, and its role in achieving customer satisfaction.

\section{References}

1. S. Alvarez, L. Busenitz, Journal of Management 27(6), 755-775 (2001)

2. P. Westhead, M. Wright, D. Ucbasaran, J. Bus. Ventur. 16, 333-358 (2001)

3. S. Laghzaoui, Journal of Innovation Economics \& Management 7(1), 181-196 (2011)

4. G.O. Oparaocha, Int. Bus. Rev. 24, 861-873 (2015)

5. European Commission Supporting the internationalization of SMEs - Good practice selection (DG Enterprise and Industry, Luxembourg, 2008)

6. European Commission and EIM Business \& Policy Research Internationalization of European SMEs, final report (DG Enterprise and Industry, Brussels, 2010)

7. W.-T.T. Hsu, H.-L.L. Chen, C.-Y.Y. Cheng, J. World Bus. 48, 1-12 (2013)

8. B. Antoncic, D. Hisrich, M. Konecnik, M. Ruzzier, Canadian Journal of Administrative Sciences: Human capital and SME internationalization: a structural equation modeling study 24(1), 15-29 (2007)

9. M. Novak, S. Bojnec, Managing Global Transitions 3(2), 157-177 (2005)

10. R. Aidis, Size matters: entrepreneurship and government. Small business economics (2012)

11. R. Singh, M.H.B. Subrahmanya, Asian J. Innov. Policy 7, 461-488 (2018)

12. Y. Chandra, I.F. Wilkinson, J. World Bus. 52, 691-701 (2017) 
13. R. Alas, E-World Entrepreneurship research (2015)

14. N. Dominguez, U. Mayrhofer, Int. Bus. Rev. 26, 1051-1063 (2017)

15. E. Galdeano-Gómez, J.C. Pérez-Mesa, J.A. Aznar-Sánchez, J. Bus. Econ. Manag. 17, 1114-1132 (2016)

16. I. Kalinic, C. Forza, Int. Bus. Rev. 21, 694-707 (2012)

17. J. Bell, D. Crick, S. Young, Int. Small Bus. J. 22, 23-56 (2004)

18. H. Etemad, R.W. Wright, L.P. Dana, Thunderbird Int. Bus. Rev. 43, 481-499 (2001)

19. H.E. Guili, D. Ferhane, Internationalization of SMEs and Effectuation: The Way Back and Forward. Proceedings 2, 1422 (2018)

20. W. Kuemmerle, A test for the faint-hearted (Harvard Business Review, 2002)

21. M. Njima, S. Demeyer, Evolution of software product development in startup companies (2017) http://ceur-ws.org/Vol-2047/BENEVOL2017paper3.pdf

22. A. Schulz, T. Borghoff, S. Kraus, International Journal of Business and Economics 9(1) (2009)

23. A. Dubgorn, M.N. Abdelwahab, A. Borremans, I. Zaychenko, Proceedings of the 33rd International Business Information Management Association Conference, IBIMA 2019: Education Excellence and Innovation Management through Vision 2020 (2019)

24. V. Anjan, Journal of Financial Intermediation, https://doi.org/10.1016/j.jfi.2019.100833

25. A.V. Thakor, Journal of Financial Economics 102(1), 130-148 (2012)

26. D. Egorov, A. Levina, S. Kalyazina, P. Schuur, B. Gerrits, Lecture Notes in Networks and Systems 157, 201-209 (2021)

27. I. Ilin, S. Maydanova, A. Lepekhin, C. Jahn, J. Weigell, V. Korablev, Lecture Notes in Networks and Systems 157, 179-188 (2021)

28. M.A. Chen, Q. Wu, B. Yang, The Review of Financial Studies 32(5), 2062-2106 (2019)

29. S. Maydanova, I. Ilin, Proceedings of the 33rd International Business Information Management Association Conference, IBIMA 2019: Education Excellence and Innovation Management through Vision 2020 (2019)

30. B. Navaretti, F. Alberto, Fintech and Banking. Friends or Foes (2018) http://dx.doi.org/ 10.2139/ssrn.3099337

31. J.F. Gubrium, J.A. Holstein, Handbook of interview research: context and method (Sage, Thousand Oaks, California, 2001) 